\title{
Mandatory Minimums and the War on Drugs
}

\author{
Daniel Wodak
}

Mandatory minimum sentencing provisions have long been a feature of the US justice system. In the Crimes Act of 1790, seven offenses, such as treason, carried a mandatory death penalty: ${ }^{1}$ that is, upon convicting a defendant for treason, the minimum sentence a judge could impose was death. From 1790 to 1950 , federal mandatory minimums grew slowly and "generally targeted crimes that were infrequent" and "decisively federal in nature", like piracy. ${ }^{2}$ With the onset of the war on drugs, mandatory minimums became a more significant feature of the justice system: "Congress passed harsh drug-related mandatory minimums in 1951 and 1956, repealed them in 1970 [...], then passed them again in a biennial fashion, beginning in 1984". ${ }^{3}$ Federal mandatory minimums have grown explosively under the war on drugs, ${ }^{4}$ become more severe, and targeted crimes that were frequent and also punishable under state laws.

The effects of this trend are myriad. Most obviously, many prisoners are subject to drug-related mandatory minimums. In 2016, 22\% of offenders in the federal system were convicted of an offense carrying a mandatory minimum and $67 \%$ of those offenders were convicted of drug trafficking; $;{ }^{5}$ of the remainder, many were also subject to mandatory minimums due to the war on drugs under firearms and "career offender" provisions. ${ }^{6}$ It would be misleading to focus only on the federal system since "half of all federal prisoners are serving time for drug crimes". ${ }^{7}$ State legislatures also passed and expanded mandatory minimums significantly during the war on drugs and in some cases due to the influence of federal crime policy. ${ }^{8}$ Drug offenders were $6.5 \%$ of the state prison population in 1980 ; this rose to $22 \%$ in 1990 before dropping to $16 \%$ today. ${ }^{9}$

D. Wodak $(\bowtie)$

Virginia Tech, Blacksburg, VA, USA

e-mail: dwodak@vt.edu

(C) The Author(s) 2018

D. Boonin (ed.), The Palgrave Handbook of Philosophy and Public Policy,

https://doi.org/10.1007/978-3-319-93907-0_5 
Three developments have brought a renewed focus on these laws. First, many argue that drug-related mandatory minimums "warrant special attention because of their incredible force in driving mass incarceration". ${ }^{10}$ This has prompted several bipartisan bills in Congress to repeal, or reduce the severity of, these laws. ${ }^{11}$

Second, US Attorney General Jeff Sessions issued a memo on May 10, 2017 instructing federal prosecutors to "charge and pursue the most serious, readily provable offense". Sessions explicitly rescinded two memos issued by then US Attorney General Eric Holder (on August 12, 2013, and September 14, 2014, respectively), which had instructed federal prosecutors not to (a) specify drug quantities which trigger mandatory minimums except for "serious, high-level, or violent drug traffickers" or (b) use one drug-related mandatory minimum, $\$ 851$, "in plea negotiations for the sole or predominant purpose of inducing a defendant to plead guilty". This reversal of policy will increase the number of prisoners affected by federal drug-related mandatory minimums.

Third, the US is in the midst of an opioid epidemic. In 2016, drug overdoses killed 60,000 Americans. ${ }^{12}$ In response, some have called for harsh new or enhanced opioid-related mandatory minimums. ${ }^{13}$ Florida Governor Rick Scott signed one such law, HB 477 on June 14, 2017. ${ }^{14}$

The US justice system is being pulled in different directions: some want to repeal drug-related mandatory minimums and curtail their use; others seek to expand such provisions and force prosecutors to apply them even more pervasively. How can philosophers help to resolve this debate?

One might think that the matter is best left to those criminologists who can determine whether drug-related mandatory minimums work. But disagreement persists in the face of such empirical evidence because mandatory minimums' defenders and detractors appeal to competing principles of justice. In this chapter, we consider three such appeals: to proportionality, consistency, and efficiency.

I will defend the view that the use of mandatory minimums in the war on drugs is unjust. A common theme will be that mandatory minimums transfer us from one type of justice system to another. Their use transfers the determination of sentences from a fine-grained system (sentencing guidelines) to a coarse-grained system (mandatory minimums); that is why they generate disproportionate sentencing. Their use also transfers discretion in sentencing from accountable judges to unaccountable prosecutors; that is why they generate inconsistency in sentencing. And their threatened use transfers resources from police and courts to prisons; this does not generate efficiency but does compromise the justice system's ability to meet its aim of protecting the rights of the innocent.

\section{PROPORTIONALITY}

One prominent argument against drug-related mandatory minimums is that they generate disproportionate punishments and thereby violate the principle that the severity of punishments should not be disproportionate to the culpability of the offender and the seriousness of the offense. ${ }^{15}$ Why would mandatory minimums violate this principle? 
It is helpful to here compare mandatory minimums to the US Sentencing Guidelines, which also emerged during the war on drugs. Senator Orrin Hatch (R-Utah) explains two important points of comparison:

Whereas the guidelines permit a degree of individualization in determining the appropriate sentence, mandatory minimums employ a relatively narrow approach under which the same sentence may be mandated for widely divergent cases. Whereas the guidelines provide for graduated increases in sentence severity for additional wrongdoing or for prior convictions, mandatory minimums often result in sharp variations in sentences based on what are often only minimal differences in criminal conduct or prior record. ${ }^{16}$

Unlike the guidelines, mandatory minimums are insensitive to a long list of individualized mitigating factors: they guarantee that some low-level offenders will receive severe sentences. And unlike the guidelines, mandatory minimums involve "sentencing cliffs": they guarantee major differences in sentences for minor differences between offenses.

Plenty of examples can illustrate these points. Like many individuals during the opioid epidemic, William Forrester became addicted to pain medication after six years of treatment for cancer. He used a fake prescription to obtain oxycodone and in 2009 was sentenced to a mandatory minimum 15 -year prison term in Florida for "drug trafficking": this was required because he possessed 15.6 grams of oxycodone. In sentencing Forrester, Judge McDonald noted that Florida's mandatory minimums require him to treat "the addicted" and "organized crime" the same way: "we can't carve exceptions that don't exist". ${ }^{17}$

In 2003, Terrance Lavar Davis pled guilty to felonious possession of 26 grams of cocaine in a school zone and delivery of 0.5 grams of cocaine in a school zone. $\mathrm{He}$ was subject to a mandatory minimum sentence of 22 years without parole because he sold cocaine at $11 \mathrm{pm}$ inside his own apartment in a gated community in Nashville, Tennessee, and his apartment was 900 feet from a school; if it were 101 feet further away, his sentence would have been 10 years shorter, and he would be eligible for parole after 4 years. ${ }^{18}$ Mandatory school zone enhancements are a prime example of sentencing cliffs: minimal differences in the location of crimes generate major differences in sentencing. They also result in significant racial disparities because racial minorities are far more likely to live in dense cities, and in dense cities few areas are not within 1000 feet of a school.

Another example of sentencing cliffs comes from minor differences in drug quantities. Under the Anti-Drug Abuse Act of 1986, if one was convicted of possessing 5.1 grams of crack cocaine, one was subject to a mandatory minimum sentence of five years, whereas if one was convicted of possessing 5 grams of crack cocaine, one would be subject to a maximum sentence of one year. ${ }^{19}$ This law was infamous because one would be subject to the same five-year mandatory minimum for possessing 500 grams of powder cocaine; that 100:1 ratio became a (less unjust) 18:1 ratio under The Fair Sentencing Act of 2010, but sentencing cliffs for minor differences in drug quantities remain a feature of the system. 
By transferring determination of sentencing from a fine-grained system to a coarse-grained one, the use of mandatory minimums in the war on drugs effectively guarantees that many offenders like Forrester and Davis will be disproportionately punished. This is unjust. And this is not to mention certain dubious prosecutorial practices which trigger disproportionate sentencing cliffs, such as "mixture inflation", ${ }^{20}$ the use of conspiracy doctrines, ${ }^{21}$ and "count stacking", 22 which I will not discuss.

\section{CONSISTENCY}

Concerns about inconsistent sentencing outcomes were rife in the 1970s and 1980s due to the discretion then afforded to judges; hence the titles of influential articles of that era, such as Judge Marvin E. Frankel's (1972) "Lawlessness in Sentencing”. Studies found that judges' responses to hypothetical cases, especially drug cases, evinced a "generally high rate of agreement on the verdict, but substantial variance in the choice of sentencing mode and the magnitude of penalty within some modes". ${ }^{23}$ A central motivation for the creation of mandatory minimums in the war on drugs was to generate more consistent sentencing outcomes. ${ }^{24}$ This was true at federal and local levels. James Forman Jr. illustrates how concerns about racial discrepancies in sentencing outcomes led to the creation of harsh drug-related mandatory minimums in the District of Columbia, due to the efforts of prominent local black politicians like John Ray. ${ }^{25}$

The sentencing guidelines were also intended to address inconsistent sentencing outcomes. But many contend that they are now inadequate for this purpose as the Supreme Court made the guidelines advisory, rather than mandatory, in Booker in 2005. ${ }^{26}$ Many judges now impose sentences that are below the guidelines, especially for drug trafficking. ${ }^{27}$ Since Booker, mandatory minimums are again defended on the ground that (a) offenders should receive similar sentences for similar crimes and (b) this requires drug-related mandatory minimums that eliminate discretion. ${ }^{28}$

A problem for this argument is that mandatory minimums do not eliminate discretion in sentencing. They transfer it to prosecutors. To understand this, it is helpful to mention Senator Hatch's third point of comparison between sentencing guidelines and mandatory minimums:

[W]hereas the guidelines incorporate a "real offense" approach to sentencing, mandatory minimums are basically a "charge-specific" approach wherein the sentence is triggered only if the prosecutor chooses to charge the defendant with a certain offense. ${ }^{29}$

Because drug-related mandatory minimums apply to conduct that is covered by other charges, they give prosecutors a choice over what charge to apply. That "choice of charge can determine both the minimum and the maximum" sentence, so in exercising this discretion "prosecutors can restrict judges to narrow sentencing ranges". ${ }^{30}$ As one commentator noted, "one premise of mandatory minimums is that the prosecutors are competent to decide appropriate sentences until they become judges". ${ }^{31}$ 
Prosecutorial discretion in applying mandatory minimums in the war on drugs results in disparate sentencing outcomes. ${ }^{32}$ So much so that many previous federal Attorneys General have issued memos to restrict prosecutorial discretion because "federal prosecutors [were] pursuing their own idea of justice". ${ }^{33}$ New Jersey implemented prosecutorial guidelines because "prosecutors in urban counties had been offering much more generous deals that those in suburban or rural counties". ${ }^{34}$ Racial disparities are also rife. For instance, prosecutors in Georgia "have unbridled discretion" to decide whether to bring a charge carrying a mandatory minimum life sentence for a second drug offense; when this practice was (unsuccessfully) challenged in 1995, prosecutors "had invoked [this discretion] against only l percent of white defendants facing a second drug conviction but against 16 percent of black defendants", so " $98.4 \%$ of those serving life sentences under the provision were black". ${ }^{35}$

The problem here is not simply that discretion has not been eliminated. It is that prosecutorial discretion is more worrisome than judicial discretion. First, the determination of sentencing is "a quintessential, historically recognized judicial function"; the "effective transfer of that power to the executive branch" via mandatory minimums undermines the separation of powers. ${ }^{36}$ And second, prosecutors are less accountable than judges. The exercise of judicial discretion in sentencing is supported by judges' written decisions, which are both reported and reviewable by superior courts. By contrast, "prosecutors have ended up with almost unfettered, unreviewable power to determine who gets sent to prison and for how long". ${ }^{37}$ And the lack of reporting mechanisms leaves us with a paucity of data for informally monitoring the use of prosecutorial discretion. ${ }^{38}$

Defenders of drug-related mandatory minimums do not deny that they give prosecutors discretion. Indeed, they invoke prosecutorial discretion in defending such laws. The National Association of Assistant United States Attorneys, for instance, argues that mandatory minimums do not produce disproportionate sentences because they are "almost never used, but instead only saved for the worst of the worst defendants". ${ }^{39}$ If this is true, how would mandatory minimums ensure consistency? ${ }^{40}$

The available data also undermine this defense. Drug-related mandatory minimums are not "almost never used". Close to $47 \%$ of federal drug offenders sentenced in 2016 were convicted of offenses carrying a mandatory minimum penalty ${ }^{41}$ Nor are they "saved for the worst of the worst defendants". Mandatory minimums are more frequently applied to less culpable offenders. In 2016, over one-third of federal offenders who were subject to a mandatory minimum penalty at sentencing had a Category I Criminal History; another third fell into Category II or Category III. ${ }^{42}$ These are the least serious of the available six categories. As we will see in $\$ I I I$, there is a simple explanation for this pattern.

Notably, many reforms that restrict prosecutorial discretion-such as Sessions' May 10, 2017, memo-force prosecutors to apply mandatory minimums more frequently, resulting in more disproportionate sentences. This suggests that the conflict between consistency- and proportionality-based principles of justice is deep. So which principle should we accept? 
One option is to eliminate the conflict between these principles by interpreting proportionality as being determined by the law. If "offenders deserve whatever the penal code provides as their punishment", ${ }^{43}$ mandatory minimums do not generate disproportionate sentences, and they should be applied consistently so everyone gets what they deserve. This view is implausible: if whatever the law requires is what the offender deserves, a mandatory minimum death penalty for jaywalking could be proportionate. Moreover, this view is inconsistent with the Supreme Court's understanding of its narrow "proportionality analysis": the Court has taken a "highly deferential" approach ${ }^{44}$ and hence upheld a mandatory minimum life sentence for possessing 672 grams of cocaine,${ }^{45}$ but it still treats legislation only as evidence of what is proportionate.

Alternatively, one might deny the principle of proportionality. Simple utilitarian views take this route. And they thereby license the punishment of the innocent: as Adam Kolber writes, "punishing innocent people is just a specialized case of over-punishment in which a person with no blameworthiness is punished in excess of desert" ${ }^{46}$ This is why simple utilitarian theories of punishment are widely rejected. ${ }^{47}$

This leaves a final option: rejecting consistency principles wherever they conflict with the principle of proportionality. ${ }^{48}$ Consistency-based defenses of mandatory minimums require the equal treatment of those subject to the same criminal charge. That is an impoverished understanding of the principle of equality. Equality is better understood in terms of treatment as equals-treating persons with equal concern and respect. ${ }^{49}$ When Judge McDonald sentenced Forrester, he noted that Florida's mandatory minimums require the equal treatment of (a) those blamelessly addicted to opioids due to over-prescription and (b) members of criminal syndicates. The equal treatment of (a) and (b) does not treat them as equals.

\section{EFFICIENCY}

While mandatory minimums are often explicitly justified by appeals to consistency, you would be in good company if you suspected that a different motivation was afoot. As the Sentencing Commission has noted, "the value of a mandatory minimum sentence lies not in its imposition, but in its value as a bargaining chip to be given away in a resource-saving plea from the defendant for a more leniently sanctioned charge". ${ }^{50}$

This appeal to saving resources rests on a utilitarian principle of justice. And it is more plausible than other utilitarian justifications for drug-related mandatory minimums, such as those that appeal to deterrence. ${ }^{51}$ But such efficiency-based justifications are rarely made explicit; other justifications are often offered as a smokescreen. ${ }^{52}$ This is true in the war on drugs. Recall Sessions' May 10, 2017, memo, which rescinded Eric Holder's September 14, 2014, policy restricting prosecutors from using a drug-related mandatory minimum "in plea negotiations for the sole or predominant purpose of inducing a defendant to plead guilty". Sessions' memo appealed to the importance of "enforc[ing] the law fairly and consistently"; he said nothing about useful threats in plea bargaining. 
How would the use of drug-related mandatory minimums as threats promote efficiency? In two ways. First, "federal prosecutors often wield the threat of the mandatory minimum to persuade a defendant to plead guilty to a charge that doesn't carry such a stiff sentence". ${ }^{53}$ These plea bargains increase the efficiency of the justice system by avoiding lengthy, expensive trials. Close to 95\% of American criminal cases are now resolved by plea bargain. The criminal justice system would grind to a halt if these cases all went to trial.

Second, mandatory minimums provide defendants with strong incentives to cooperate with prosecutors in order to either plead to a lesser charge or receive a reduced sentence for "substantial assistance" under U.S.C. $\$ 3553(\mathrm{e})$. In 2016 , roughly $25 \%$ of offenders, and $30 \%$ of drug trafficking offenders, who were convicted of offenses that carried a mandatory minimum penalty received a reduced penalty under $\$ 3553(\mathrm{e}) .{ }^{54}$ This practice also generates inconsistent sentencing outcomes. But it is held to be vital to the war on drugs. As Jodi L. Avergun, then chief of staff at the Drug Enforcement Agency, argued in a 2005 Congressional hearing:

In drug cases, where the ultimate goal is to rid society of the entire trafficking network, mandatory minimum statutes are especially significant. Unlike a bank robbery, for which a bank teller or ordinary citizen could be a critical witness, often in drug cases the critical witnesses are drug users and other drug traffickers. The offer of relief from a mandatory minimum sentence in exchange for truthful testimony allows the Government to move steadily and effectively up the chain of supply, using lesser distributors to prosecute the more serious dealers and their leaders and suppliers. ${ }^{55}$

Using mandatory minimums as threats to compel cooperation is seen as an efficient means toward this "ultimate end" of the war on drugs.

The importance of the pervasive use of mandatory minimums as a threat by prosecutors is hard to overstate. And yet it is also often ignored. Consider William Stuntz's diagnosis of the cause of mass incarceration:

The rising number of inmates was chiefly due to the rise in the number of defendants charged and convicted. [...] Drugs were a significant factor in the exploding prison population, but they are not the explosion's primary cause-and the same is true of the three-strikes laws and mandatory minimums that increased punishment for various classes of non-drug crime. More inmates live in state and federal penitentiaries than in the past chiefly because prosecutors have charged and convicted more criminal defendants than in the past. ${ }^{56}$

Stuntz may be right that the imposition of mandatory minimum sentences for drug and non-drug crime is not the "primary cause" of mass incarceration. But the threat of such charges is key to "the rise in the number of defendants charged and convicted". Without this, prosecutors could not get evidence against and run trials of so many defendants.

This should make us question the degree to which mandatory minimums promote efficiency. If it is this easy for prosecutors to charge and convict so 
many people, the land of the free will continue to be, unenviably, the world leader in locking up its own citizens. There are many reasons to oppose mass incarceration, but the one that is most germane here is that it involves a remarkably inefficient resource allocation. Federal correction costs increased $925 \%$ from 1982 to $2007^{57}$ and now consume over a quarter of the Department of Justice's budget. As prison budgets have increased, legislatures have cut funding for state and local law enforcement (by 76\%, since 1998). ${ }^{58}$ Yet the return on investment for funding police is far better: "a dollar spent on police goes at least 20 percent further than a dollar spent on corrections". ${ }^{59}$ So the use of mandatory minimums as threats does not save resources; it transfers them from police to prisons.

There are three further reasons to reject this appeal to efficiency. The first is that threatening severely disproportionate punishments in order to secure plea bargains coercively undermines the right to trial. This practice has been considered constitutional by the Supreme Court in Bordenkircher v. Hayes. ${ }^{60}$ But it is still odious for a defendant like Hayes to face the prospect of a mandatory minimum sentence of life imprisonment without parole, rather than a five-year sentence, for exercising the right to trial by jury.

A second concern with the use of mandatory minimums as threats is that this predictably results in the punishment of the innocent. Consider the position of an innocent defendant who is offered a choice like Hayes'. Most defendants rely on a public defender, who can often "spend only minutes with their clients before deciding whether to accept a plea deal", during which time they cannot provide much advice, especially since "defendants have almost no constitutional right to discovery during the plea process, [so] prosecutors are often able to convincingly bluff with weak hands". ${ }^{61}$ (And many prosecutors do bluff. ${ }^{62}$ ) Many innocent defendants will plead guilty in the face of such threats: "[s]imply by charging someone with an offense carrying a mandatory sentence of ten to fifteen years or life, prosecutors are able to force people to plead guilty" to lesser offenses, including "many innocent drug defendants". ${ }^{63}$ Empirical evidence suggests that the majority of innocent defendants will still go to trial. ${ }^{64}$ Of those, many are convicted, and face severe mandatory minimums. In 1999 in Tulia, Texas, 43 innocent defendants were arrested for selling cocaine; the first two who refused plea bargains were tried, convicted, and sentenced to 99 and 434 years of imprisonment, respectively. ${ }^{65}$ The threatened use of mandatory minimums thus results in the unjust punishment of the innocent via compelling innocent defendants to plead guilty (to lesser offenses) and penalizing innocent defendants who use their right to trial but are wrongfully convicted (of more severe offenses). Defending the use of drug-related mandatory minimums requires a cavalier stance toward punishing the innocent.

A final problem with this appeal to efficiency concerns the usefulness of compelled cooperation. In many cases, prosecutors do not use threats against "lesser distributors" to move up the chain of supply "to prosecute the more serious dealers and their leaders and suppliers". If anything, they do the opposite: prosecutors offer reduced sentences to more serious offenders who have valuable 
information to gain evidence against lesser distributors. Consider United States v. Brigham, where a driver received a 10 -year mandatory minimum while a drug kingpin received a reduced sentence ( 84 months) for providing "substantial assistance". Judge Easterbrook, while affirming this sentence on appeal, wrote that:

Mandatory minimum penalties, combined with a power to grant exemptions, create a prospect of inverted sentencing. The more serious the defendant's crimes, the lower the sentence- because the greater his wrongs, the more information and assistance he has to offer to a prosecutor. ${ }^{66}$

Inverted sentencing not only involves disproportionate punishments, but undermines the claim that mandatory minimums are vital to the war on drugs. For prosecutors to give lower sentences to kingpins in order to fry the smaller fish hardly helps rid society of drug trafficking networks. ${ }^{67}$ It makes it harder to achieve that goal because the perception of unfair and overly punitive sentencing practices generates a "cooperation backlash": it "leads victims and witnesses of crime to think twice before cooperating with law enforcement". ${ }^{68}$ Victims and witnesses would provide more reliable evidence. "Who among us", Alexander asks, "would not be tempted to lie if it was the only way to avoid a forty-year sentence for a minor drug crime?" 69 A policy that trades sources of good information for sources of bad information is hard to justify on utilitarian grounds.

\section{Conclusion}

In this chapter, I have explored three common arguments regarding the use of mandatory minimums in the war on drugs. Because mandatory minimums transfer the determination of sentences from fine-grained sentencing guidelines to coarse-grained system mandatory minimums, they generate disproportionate punishments. And because mandatory minimums transfer discretion from accountable judges to unaccountable prosecutors, and transfer resources from police to prisons, they are difficult to justify on the grounds of consistency or efficiency. For these reasons, the use of mandatory minimums in the war on drugs is unjust.

\section{Notes}

1. US Sentencing Commission, 2011 Report to the Congress: Mandatory Minimum Penalties in the Federal Criminal Justice System (Washington D.C.: USSC, 2011 ), ch. 2.

2. Naomi Murakawa, The First Civil Right: How Liberals Built Prison America (Oxford University Press, 2014), 116. As Murakawa notes (242), in 1914 "Congress enacted a five-year mandatory minimum for opium manufacture"; this was the only drug-related federal mandatory minimum passed until the Boggs Act in 1951. 
3. Murakawa, The First Civil Right, 119.

4. Murakawa quantifies this: The First Civil Right, 24, 116, 241.

5. US Sentencing Commission, Quick Facts on Mandatory Minimums (Washington D.C.: USSC, 2017a).

6. Close to $50 \%$ of the offenders convicted under $\$ 924(\mathrm{c})$ were convicted of carrying a firearm in the commission of a drug trafficking felony, and over $75 \%$ of career offenders convicted under $\$ 924$ (e) were sentenced for a drug trafficking offense (see U.S. Sentencing Commission, Quick Facts on $\$ 924(\mathrm{c})$ Firearms Offenses (Washington D.C.: USSC, 2017b) and Quick Facts on Career Offenders (Washington D.C.: USSC, 2017c)). The latter figure does not count cases where past drug convictions are what cause a future conviction to trigger a career offender enhancement: see John Pfaff, Locked In: The True Causes of Mass Incarceration and How to Achieve Real Reform (Basic Books, 2017), 41.

7. Pfaff, Locked In, 13.

8. See, for example, Murakawa, The First Civil Right, 64.

9. Pfaff, Locked In, 6, 13, 22.

10. Murakawa, The First Civil Right, 115. This is part of what Pfaff calls the "Standard Story".

11. In 2013, Senators Durbin (D-IL), Leahy (D-VT), and Lee (R-UT) proposed the Smarter Sentencing Act, and Leahy and Paul (R-KY) proposed the Judicial Safety Valve Act.

12. "Drug Deaths in America Are Rising Faster Than Ever", New York Times, June $5,2017$.

13. See, for example, "Grand Jury Calls for Mandatory Minimums to Fight Opioids”, U.S. News, May 18, 2017.

14. "Rick Scott signs tough new mandatory minimums for fentanyl into law", Miami Herald, June 14, 2017.

15. See, for example, Antony Duff and Zachary Hoskins, 'Legal Punishment', in Edward N. Zalta (ed.) The Stanford Encyclopedia of Philosophy (2017).

16. Hatch, cited by Paul Cassell, 'Too Severe? A Defense of the Federal Sentencing Guidelines (And a Critique of the Federal Mandatory Minimums), Stanford Law Review 56 (2004), 1045. See also United States v. Harris, 536 U.S. 545, 570 (2002) (Breyer, J., concurring) ("Mandatory minimum statutes are fundamentally inconsistent with Congress' simultaneous effort to create a fair, honest, and rational sentencing system through the use of Sentencing Guidelines").

17. Lauren Krisai, 'Smart on Sentencing: Safety Valve for Florida's Drug Trafficking Offenses', James Madison Institute (March 20, 2017), 6.

18. See Davis v. State of Tennessee, No. M2009-00011-SC-RIl-HC. (2010).

19. US Sentencing Commission, Special Report to the Congress: Mandatory Minimum Penalties in the Federal Criminal Justice System (Washington D.C.: USSC, 1991), 31; Jonathan P. Caulkins, Peter Rydell, and William L. Schwabe, 'Mandatory Minimum Drug Sentences: Throwing Away the Key or the Taxpayers’ Money?’ (Santa Monica, CA: RAND Corporation, 1997), 16.

20. Murakawa, The First Civil Right, 241.

21. Stephen J. Schulhofer, 'Rethinking Mandatory Minimums', 28 Wake Forest Law Review 207 (1993), 212.

22. See Alexander Sarch and Daniel Wodak, 'Resolving Judicial Dilemmas', Virginia Journal of Criminal Law (2018) 936. 
23. William Austin and Thomas A. Williams III, 'A Survey of Judges' Responses to Simulated Legal Cases: Research Note on Sentencing Disparity', 68 Journal of Criminal Law and Criminology 306 (1977), 308.

24. Kate Stith, and Steve Y. Yoh, 'The Politics of Sentencing Reform: The Legislative History of the Federal Sentencing Guidelines', 28 Wake Forest Law Review 223 (1993).

25. James Forman Jr., Locking Up Our Own: Crime and Punishment in Black America (Farrar, Straus and Giroux, 2017), 133.

26. United States v. Booker, 543 U.S. 220 (2005).

27. See US Sentencing Commission, 2012 Report to The Congress: Continuing Impact of United States v. Booker on Federal Sentencing (Washington D.C.: USSC, 2012).

28. See, for example, Forbes, quoted in Margaret Haerens (ed.), Mandatory Minimum Sentencing: Opposing Viewpoints, Greenhaven Press (2010), 21-22.

29. Hatch, cited by Cassell, 'Too Severe?', 1045.

30. Pfaff, Locked In, 131 .

31. Ibid, quoting Newburn. See also Jeffrey T. Ulmer, Megan C. Kurlychek, \& John H. Kramer, 'Prosecutorial Discretion and the Imposition of Mandatory Minimum Sentences', 44 Journal of Research in Crime and Delinquency 427 (2007), Angela Davis, 'The American Prosecutor: Independence, Power, and the Threat of Tyranny', 86 Iowa Law Review 393 (2001), David Bjerk, 'Making the Crime Fit the Penalty: The Role of Prosecutorial Discretion Under Mandatory Minimum Sentencing', 48 Journal of Law and Economics 591 (2005).

32. See USSC (2011), 109-114.

33. Pfaff, Locked In, 55 .

34. Id., p. 149.

35. Michelle Alexander, The New Jim Crow: Mass Incarceration in the Age of Colorblindness (revised edition, The New Press, 2012) 114. See also Barbara S. Vincent, \& Paul J. Hofer, Federal Judicial Center, 'The Consequences of Mandatory Minimum Prison Terms: A Summary of Recent Findings' 3 (1994), 23.

36. Erik Luna, and Paul Cassell, 'Mandatory Minimalism', 32 Cardozo Law Review. $1(2010), 70$. See also references therein.

37. Pfaff, Locked In, 70.

38. Pfaff, Locked In, 17, 42.

39. NAAUSA, quoted by Pfaff, Locked In, 132.

40. A similar point holds for "safety valves" under U.S.C. $\$ 3553$ (f). Senator Hatch, who proposed this provision, explained it as a "narrow reform needed to return a small degree of discretion to the courts for a small percentage of nonviolent drug cases” (139 Cong. Rec. 27,842) (Nov. 8, 1993) (statement of Sen. Hatch).

41. USSC (2017a).

42. US Sentencing Commission, Overview of Mandatory Minimum Penalties in the federal Criminal Justice System (Washington D.C.: USSC, 2017d), 38.

43. See Hugo Adam Bedau and Erin Kelly, 'Punishment', in Edward N. Zalta (ed.), The Stanford Encyclopedia of Philosophy (Fall 2015 Edition), $\$ 3$.

44. Graham v. Florida, 130 S. Ct. 2011, 2036-2037 (2010) (Roberts, C.J., concurring).

45. Harmelin v. Michigan, 111 S. Ct. 2680 (1991). See also Sarch and Wodak, 'Resolving Judicial Dilemmas'.

46. Adam Kolber, 'The Comparative Nature of Punishment', Boston University Law Review, 89 (2009), 1606. 
47. See, for example, H.J. McCloskey, 'A Non-Utilitarian Approach to Punishment', in Gertrude Ezorsky (ed.) Philosophical Perspectives on Punishment (State University of New York Press, 1972), 129.

48. See the USSC (1991)'s stance on "unwarranted sentencing uniformity".

49. Ronald Dworkin, Taking Rights Seriously (Harvard University Press, 1977), 370.

50. USSC, quoted by Alexander, The New Jim Crow, 88.

51. On the general paucity of data about supporting the view that harsher sentences reduce crime through general deterrence, see Anthony N. Doob, \& Cheryl Marie Webster, 'Sentence Severity and Crime: Accepting the Null Hypothesis', 30 Crime and Justice 143 (2003). On the evidence of drug-related mandatory minimums' low deterrent value, see Christopher Mascharka, 'Mandatory Minimum Sentences: Exemplifying the Law of Unintended Consequences' 28 Florida State University Law Review 2001, 946. Michael Tonry reviewed several decades of research on drug- and firearm-related mandatory minimums and found that "the weight of the evidence clearly shows that enactment of mandatory penalties has either no demonstrable marginal deterrent effects or shortterm effects that rapidly waste away" ('Mandatory Penalties', in Michael Tonry (ed.) Crime o Justice: A Review of Research, 1990, 243-244). See also Schulhofer, 'Rethinking Mandatory Minimums'.

52. William Stuntz, The Collapse of American Criminal Justice (Harvard University Press, 2011), 82.

53. Pfaff, Locked In, 132.

54. USSC (2017a) and Quick Facts on Drug Trafficking Offenses (Washington D.C., 2017e).

55. Avergun, in Haerens (ed.), Mandatory Minimum Sentencing, 50-51.

56. Stuntz, The Collapse of American Criminal Justice, 47. A similar position is defended at length by Pfaff, Locked In, 70-76.

57. Haerens, Mandatory Minimum Sentencing, 147.

58. See Families Against Mandatory Minimums, 'How Federal Mandatory Minimums for Nonviolent Drug Offenders Make Us Less Safe': http://famm.org/ how-federal-mandatory-minimums-for-nonviolent-drug-offenders-make-usless-safe/.

59. Pfaff, Locked In, 11, citing Steven Levitt.

60. 434 U.S. 357 (1978).

61. Pfaff, Locked In, 137, 133.

62. Angela Davis, Arbitrary Justice: The Power of the American Prosecutor (Oxford University Press, 2007), 31-33.

63. Alexander, The New Jim Crow, 88.

64. See Avishalom Tor, Oren Gazal-Ayal, and Stephen M. Garcia, 'Fairness and the Willingness to Accept Plea Bargain Offers', 7 Journal of Empirical Legal Studies 2010, 99-100, and citations therein.

65. Ibid.

66. 977 F.2d 317 (7th Cir. 1992) at 318.

67. Anecdotal evidence suggests that there are plenty of examples of this practice that do not receive much media attention. See John S. Martin Jr., 'Why Mandatory Minimums Make No Sense', 18 Notre Dame Journal of Law, Ethics and Public Policy, 2004, 315-316.

68. Holder, in Mandatory Minimum Sentencing, 91.

69. Alexander, The New Jim Crow, 88, discusses the "notorious unreliability" of snitches. 